\title{
PETROLOGICAL CHARACTERS OF THE EARLY CRETACEOUS BOEOTHIAN FLYSCH, (CENTRAL GREECE)
}

\author{
K. Kyriakopoulos ${ }^{1}$, V. Karakitsios ${ }^{1}$, M. Tsipoura-Vlachou ${ }^{1}$, G. Barbera ${ }^{2}$, \\ P. Mazzoleni ${ }^{2}$ and D. Puglisi ${ }^{2}$ \\ ${ }^{1}$ National and Kapodistrian University of Athens, Faculty of Geology and Geoenvironment, \\ Panepistimioupolis Gr-15784, Ano Ilissia, Athens Greece, \\ ckiriako@geol.uoa.grvkarak@geol.uoa.grmvlachou@geol.uoa.gr \\ ${ }^{2}$ Dipartimento di Scienze Geologiche University of Catania, Corso Italia Corso Italia 55, \\ 95129 Catania-Italy, g.barbera@unict.itpmazzol@unict.itdpuglisi@unict.it
}

\begin{abstract}
This paper is aimed to study the petrographic characters of the Boeothian Flysch, an Early Cretaceous turbidite deposit which marks the boundary between the External/Internal Hellenides in central-southern Greece, in order to define a preliminary palaeogeographic reconstruction of the Pindos segment of the Alpine Tethys.

The Boeothian Flysch is mainly made up by basal conglomerates and arenaceous-pelitic lithofacies, locally interlayered with Calpionellid micrite limestones.

This formation is here supposed to belong to the Early Cretaceous flysch family, which marks the contact between the internal and external areas along all the western and central European Alpine Chains for more than 7,000 km, from the Gibraltar Arc to the Balkans via the Calabria-Peloritani Arc.

Provenance of these flysch is commonly connected to internal areas, mainly made up by Hercynian crystalline basements and, locally, by ophiolitic complexes.

The petrographic data obtained from representative sandstones of the Boeothian Flysch suggest a provenance from internal sources, formed by a Jurassic carbonate platform, metamorphic basements and by ophiolitic complexes, which can be identified with the Pelagonian Terranes (Auct.).

An Early Cretaceous uplift and rejuvenation processes, probably related to the late Cretaceous tectogenesis, widely recorded in almost all the central-western Alpine Tethis, affected these internal domains with consequent production of abundant detrital supply in the innermost sector of the Pindos Ocean, whose external margin was bounded by the Parnassos microcontinent.
\end{abstract}

Key words: External Hellenides, Early Cretaceous flysch, sandstone petrography, provenance, palaeogeographic reconstruction.

\section{Indroduction}

\section{Early Cretaceous flysch along the Europe Alpine and Betic-Maghrebian Chains; correlations and palaeogeographic significance}

The boundary between the internal and external areas in the western and central Europe Alpine 


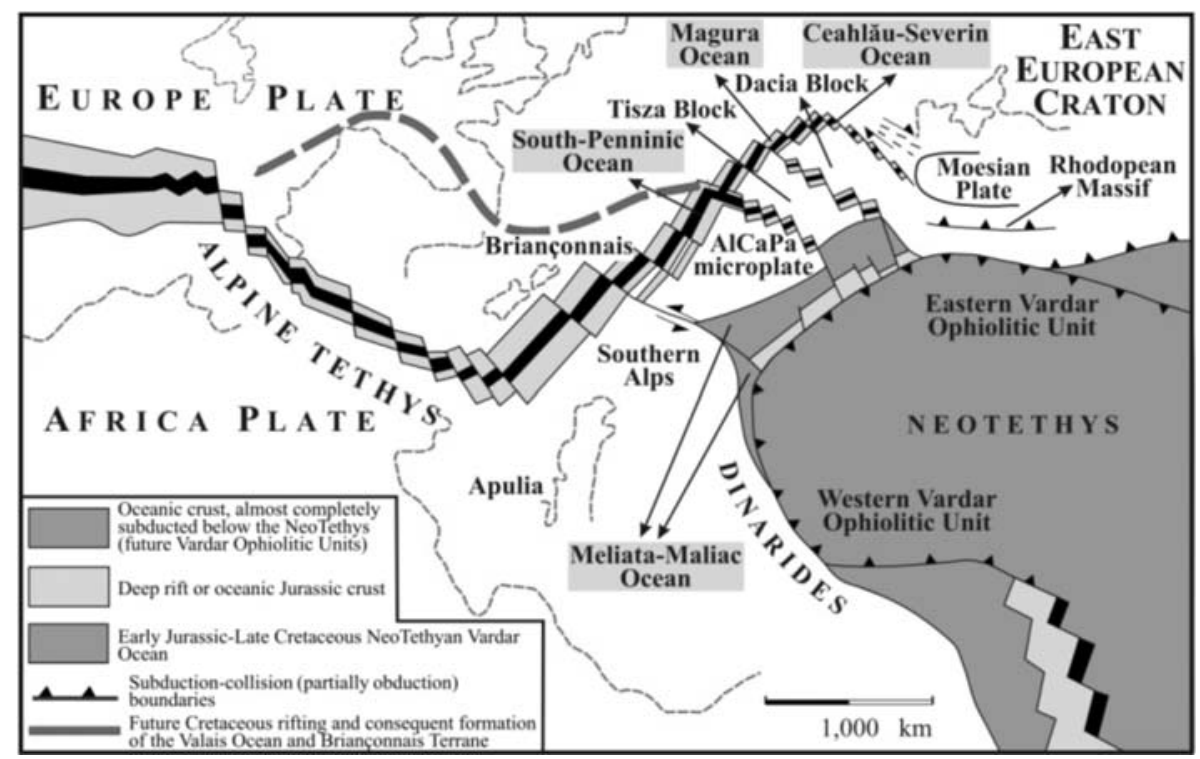

Fig. 1: Large-scale palaeogeographic reconstruction for Late Jurassic (from Puglisi 2009, modified by Channell and Kozur 1997, Csontos and Vörös 2004; Stampfli 2005; Schmid et al. 2008).

Chains is usually marked by the presence of Early Cretaceous flysch.

These crop out for more than 7,000 km from the Gibraltar Arc (Betic-Rifian Chain, Los Nogales and Jebel Tisirène Flysch, in Spain and Morocco, respectively) to the Calabria-Peloritani Arc (Monte Soro Flysch in Sicily), via the Maghrebian Chain (Guerrouch Flysch in Algeria) as far as the Balkans, through Apennines, Alps, Dinarides (Bosnian Flysch), Hellenides (Boeothian Flysch) and Carpathians (Sinaia Flysch).

These turbidite sequences (Late Jurassic-Early Paleocene) were deposited in sedimentary basins connected with the break-up of the Pangaea (Alpine Tethys s. 1.), which started an early process of closure, due to their Late Cretaceous-Early Tertiary convergence-related evolution with subduction of oceanic lithosphere and consequent formation of large ophiolitic bodies (Schmid et al. 2004; Schmid et al. 2008 and references therein).

The following two steps summarize the Mesozoic tectonic history of these palaeogeographic elements:

1- rifting with formation of oceanic troughs or large oceans (Alpine Tethys), coupled with the drifting of microcontinents during Middle Triassic to Late Jurassic times,

2- successive convergence of the plates, with subduction of oceanic lithosphere, collision of continents and nappe emplacement. These compressive events reached their highest intensity at Late Jurassic, Early and Mid-Cretaceous (Albian).

Thus, almost all the oceans of the central Alpine Tethys (Ligurian-Piedmont, Vahicum and Valais Oceans and Rhenodanubian Flysch Basin; Fig. 2) as well the easternmost sectors (Magura Basin, Pieniny Klippen Belt, Severin-Ceahlău Ocean and "Nish-Troyan flysch trough" in the Carpathians and Balkans) experienced a middle-late Cretaceous plate tectonic re-organization with consequent strong deformations of the Early Cretaceous flysch (Oszczypko 2006; Săndulescu 1994; Plašienka 


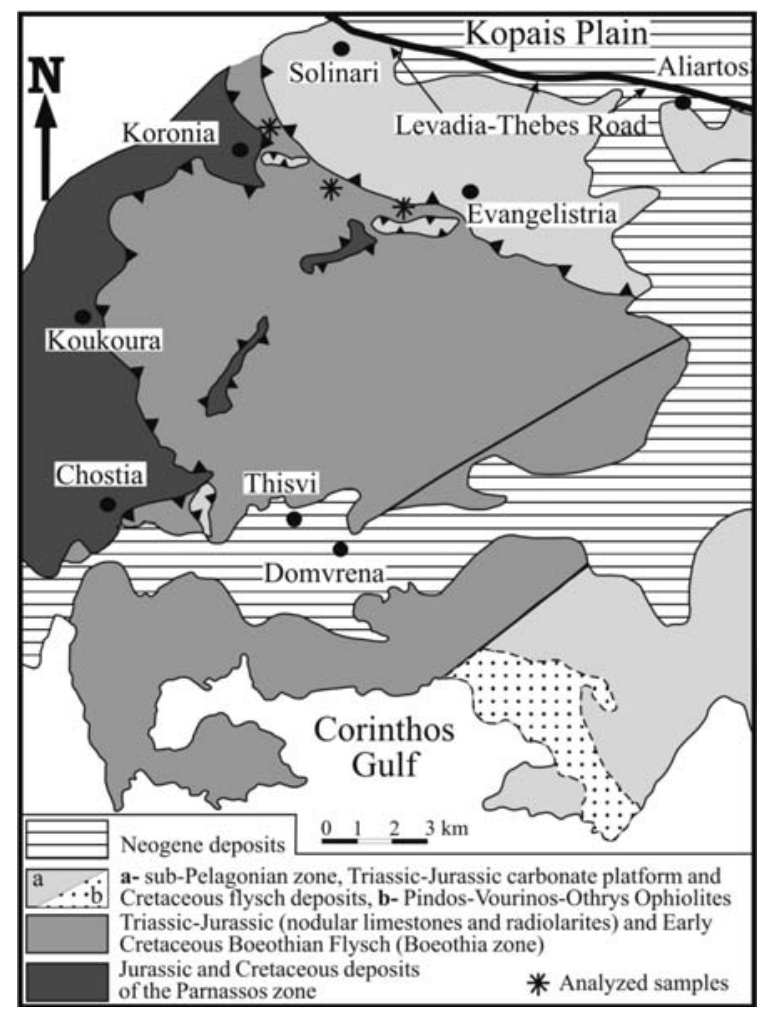

Fig. 2: Geological sketch map of the southern Boeothia (central-southern Greece), where the analyzed samples have been collected.

2003; Zagorchev 2001; Schmid et al. 2008).

Nevertheless, only the Maghrebian Chain seems to have escaped these tectonic events, which have never been recorded or, if recognized, they have often been neglected and/or not sufficiently emphasized (Puglisi 2009).

In particular, the Boeothian Flysch (Clément 1971; Celet et al. 1974; Celet et al. 1976), object of this paper, represents an early Cretaceous flysch of the Hellenides segment of the Alpine Chain probably deposited in the inner sector of the Pindos Ocean, an Early Triassic-to-Eocene basin located between the Apulian microplate and the Pelagonian terranes (Biju-Duval et al. 1977; Channel and Kozur 1997; Van Hinsbergen et al. 2009).

This study, mainly performed by a petrographic approach, is mainly focused on verifying this palaeogeographic scenario and to compare the petrographic features of the Boeothian Flysch with other coeval deposits of different sectors of the central Europe Alpine Chains, in order to emphasize the existence of a same tectonic framework.

\section{Geological setting of the Boeothian Flysch}

The Boeothian Flysch crops out in the innermost sector of the External Hellenides (southern part of the Boeothia, south of the Kopais plain, Fig. 2) and it represents a thin turbidite sequence (30 to 120 

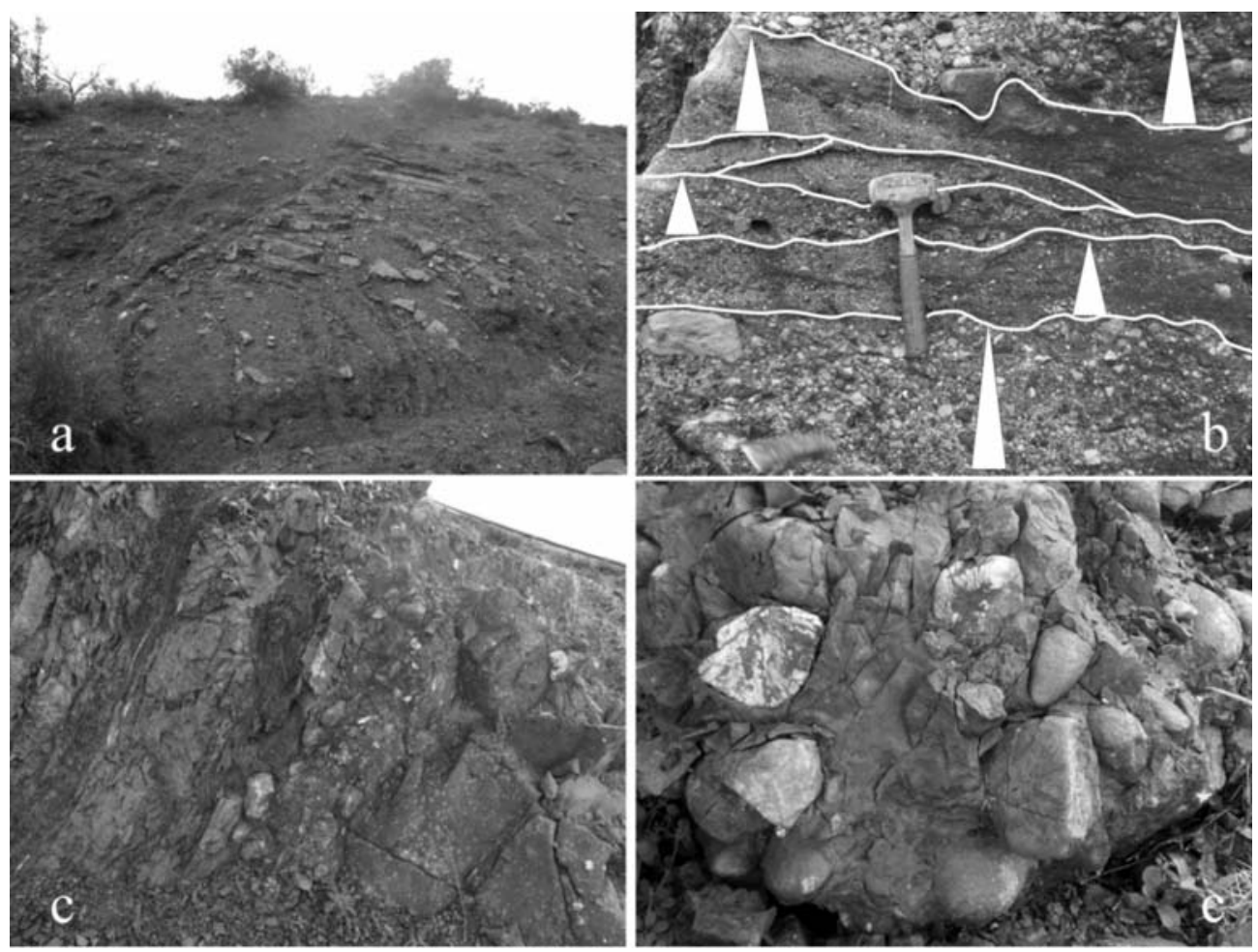

Fig. 3: a) Typical arenaceous-pelitic lithofacies of the Boeothian Flysch with thin- to medium-bedded sandstones and shale interlayers; b) stratified, gravelly graded and amalgamated medium- to coarse-grained turbidites, interlayered with organized clast-supported conglomerates; c) disorganized and clast-supported conglomerate horizons, sporadically with scarce sandy-gravelly matrix, characterizing the base of the Boeothian Flysch; d) disorganized conglomerates with subrounded pebbles and rare boulders, floating into an abundant fine- to medium-grained siliciclastic sandy matrix.

m thick), formed by a rhythmic succession of variegated marls, shales, thin-bedded sandstones (Fig. 3) and marly limestones, with conglomerate horizons in its lower part.

Limestone beds, locally rich in calpionellids, have been aged to Upper Berriasian (Newmann and Zacher 2004, and references therein).

The sedimentary basin of the Boeothian Flysch can tentatively been identified with the innermost sector of the Pindos Ocean, which represented one of the two branches of the central sector of the Neotethys Ocean (Pindos Ocean to the west and Vardar-Axios Ocean to the east; Clift 1992; Degnan and Robertson 1998), separated by the Pelagonian microcontinent.

The Boeothian Flysch represents the first siliciclastic sedimentary input in the Pindos Ocean, occurred during Early Cretaceous times, when westerly directed compressions affected the Pelagonian microcontinent, leading the progressive suturing of the Hellenide orogenetic belt.

This compression firstly emplaced remnants of the Vardar-Axios Ocean (ophiolite obduction) onto the Pelagonian microcontinent during Early Cretaceous times, while the subduction of the Pindos oceanic basement eastwards beneath the Pelagonian microcontinent continued until the 


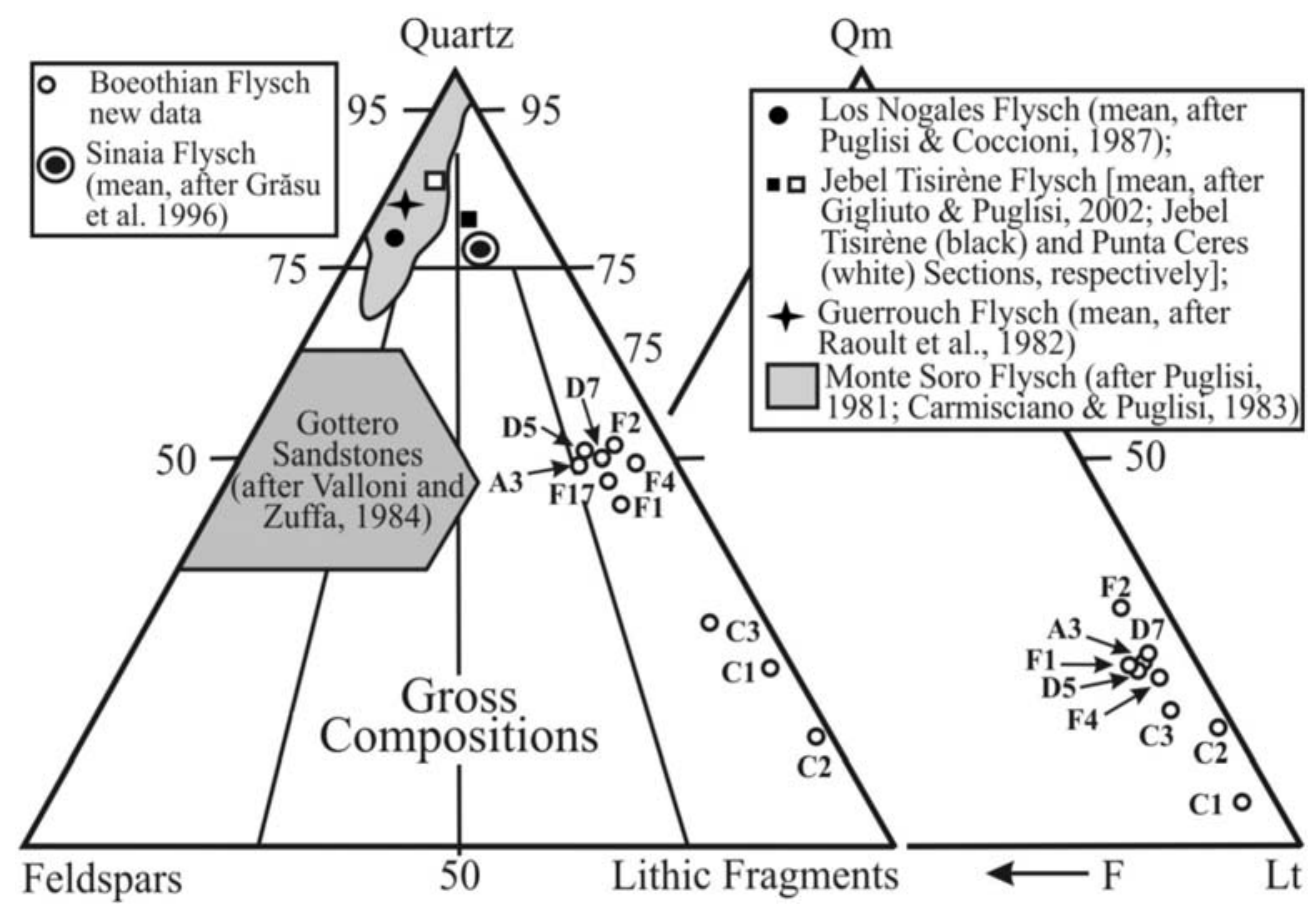

Fig. 4: Triangular plots showing the framework modes of the analyzed terrigenous arenites compared with the mean values of analogous Early Cretaceous flysch sandstones of the Maghrebian Chain (i. e. Los Nogales, Tisirène, Guerrouch and Monte Soro Flysch), northern Apennines (Gottero Sandstones) and eastern Carpathians (Sinaia Flysch). Quartz-Feldspar-Lithic Fragment and Monocrystalline quartz grains-Feldspars-Total lithic fragments diagrams, on left and wright respectively.

end of Cretaceous with accretion of the main volume of Mesozoic-Upper Cretaceous sediments of the Pindos Ocean basin to the western margin of the Pelagonian microcontinent.

Furthermore, the Late Cretaceous sedimentary evolution of the Pindos Ocean is marked by abundant radiolarian and organic-rich facies, followed by a Middle Cenomanian sediment-starved characterized by the presence of black shales, suddenly interrupted by new calcareous and/or siliciclastic turbidite events during Late Cretaceous times (Newmann and Zacher 2004).

\section{Petrographic characters of the Boeothian Flysch sandstones}

The analyzed Boeothian Flysch sandstones show grain size ranging between -1,5 $\phi$ and $0 \phi$ and they are formed by abundant ophiolitic clasts, sub-angular to sub-rounded quartz grains and by a mainly metamorphic and carbonate lithic fraction.

The lithology of the carbonate rock fragments is much diversified (micritic and peloid limestones, calcarenites and breccia limestones, locally rich in algal and sponge fragments.

The results of the modal analyses, performed by thin section point-counting according to the criteria suggested by Dickinson (1970), Gazzi et al. (1973) and Graham et al. (1976), listed in Table 1, show: 
Table 1. Modal point counts of the Boeothian Flysch sandstones.

\begin{tabular}{|c|c|c|c|c|c|c|c|c|c|c|c|}
\hline & & A3 & C1 & $\mathrm{C2}$ & C3 & D5 & D7 & F1 & F2 & F4 & F17 \\
\hline \multirow{3}{*}{$\mathbf{Q}$} & Qm & 118.8 & 7.4 & 11.1 & 10.7 & 19.4 & 20.7 & 17.6 & 20.6 & 19.2 & 17.5 \\
\hline & Qp & 21.3 & 11.6 & 13.0 & 12.4 & 27.5 & 26.8 & 20.9 & 25.3 & 24.2 & 22.9 \\
\hline & Ch & 2.4 & 0.6 & 0.9 & 1.3 & 2.1 & 1.5 & 1.1 & 2.2 & 1.7 & 1.4 \\
\hline \multirow{2}{*}{$\mathbf{F}$} & Ps & 5.3 & 2,5 & 3.5 & 4.9 & 6.3 & 5.9 & 5.7 & 4.3 & 3.9 & 5.5 \\
\hline & Ks & - & - & - & - & - & - & 0.4 & 0.7 & - & 0.9 \\
\hline \multirow{21}{*}{$\mathbf{L}$} & $\mathrm{C}$ & 10.3 & 40.5 & 36.3 & 36.6 & 17.6 & 15.0 & 7.0 & 8.5 & 6.4 & 9.9 \\
\hline & Oph & 13.7 & 15.8 & 13.8 & 10.3 & 5.7 & 7.2 & 16.9 & 14.7 & 13.7 & 8.5 \\
\hline & Ls & 5.8 & 3.1 & 4.3 & 6.1 & 3.3 & 6.9 & 2.3 & 1.7 & 4.3 & 0.9 \\
\hline & Lm & 10.1 & 11.9 & 9.6 & 8.7 & 10.5 & 11.3 & 17.1 & 12.6 & 17.4 & 19.7 \\
\hline & Ms & 2.3 & - & - & 1.7 & 3.4 & 1.1 & 1.2 & 1.1 & 1.9 & 3.5 \\
\hline & Op & 2.1 & 2.4 & 1.9 & 2.9 & - & - & 0.8 & 1.9 & 2.5 & 1.7 \\
\hline & Mt & 6.2 & 4.2 & 5.6 & 4.4 & 4.2 & 3.6 & 6.9 & 4.9 & 0.9 & 1.3 \\
\hline & $\mathrm{Cm}$ & 1.7 & - & - & - & - & - & 2.1 & 1.5 & 3.9 & 6.3 \\
\hline & & 100.0 & 100.0 & 100.0 & 100.0 & 100.0 & 100.0 & 100.0 & 100.0 & 100.0 & 100.0 \\
\hline & $\mathbf{Q}$ & 48.4 & 21.0 & 13.4 & 26.8 & 53.0 & 51.4 & 44.5 & 53.1 & 49.7 & 47.9 \\
\hline & $\mathbf{F}$ & 6.0 & 2.7 & 1.9 & 5.4 & 6.8 & 6.2 & 6.9 & 5.5 & 4.3 & 7.3 \\
\hline & $\mathbf{L}$ & 45.6 & 76.3 & 84.7 & 67.8 & 40.2 & 42.4 & 48.6 & 41.4 & 46.0 & 59.4 \\
\hline & & 100.0 & 100.0 & 100.0 & 100.0 & 100.0 & 100.0 & 100.0 & 100.0 & 100.0 & 100.0 \\
\hline & Qm & 21.5 & 7.9 & 12.0 & 11.8 & 21.0 & 21.7 & 19.8 & 22.7 & 21.1 & 20.1 \\
\hline & $\mathbf{F}$ & 6.0 & 2.7 & 1.9 & 5.4 & 6.8 & 6.2 & 6.9 & 5.5 & 4.3 & 7.3 \\
\hline & $\mathbf{L t}$ & 72.5 & 89.4 & 86.1 & 82.8 & 72.2 & 72.1 & 73.3 & 71.8 & 74.6 & 72.6 \\
\hline & & 100.0 & 100.0 & 100.0 & 100.0 & 100.0 & 100.0 & 100.0 & 100.0 & 100.0 & 100.0 \\
\hline & $L c^{*}+\mathbf{L s}$ & 40.4 & 61.4 & 63.9 & 69.9 & 56.3 & 54.2 & 23.4 & 31.3 & 25.6 & 27.7 \\
\hline & $\mathbf{L m}$ & 25.3 & 16.6 & 14.8 & 13.8 & 28.3 & 28.0 & 38.5 & 31.7 & 41.6 & 50.5 \\
\hline & Oph & 34.3 & 22.0 & 21.3 & 16.3 & 15.4 & 17.8 & 38.1 & 37.0 & 32.8 & 21.8 \\
\hline & & 100.0 & 100.0 & 100.0 & 100.0 & 100.0 & 100.0 & 100.0 & 100.0 & 100.0 & 100.0 \\
\hline
\end{tabular}

Symbols of the parameters adopted for the modal analysis

$\mathbf{Q}=\mathbf{Q m}+\mathbf{Q p}$, where: $\mathbf{Q}=$ total quartzose grains including $\mathbf{Q m}=$ monocrystalline quartzose grains,

$\mathbf{Q p}=$ polycrystalline quartzose grains and $\mathbf{C h}=$ chert;

$\mathbf{F}=$ total feldspar grains, nearly exclusively represented by single grains of plagioclase $(\mathbf{P s})$;

$\mathbf{L}=\mathbf{L c}+\mathbf{L m}+\mathbf{L s}+\mathbf{O p h}$, where: $\mathbf{L}=$ unstable fine-grained rock fragments $(<0.06 \mathrm{~mm}$, including: $\mathbf{L s}=$ terrigenous sedimentary, $\mathbf{L c}=$ carbonate, $\mathbf{L m}=$ epimetamorphic lithic fragments $), \mathbf{O p h}=$ ophiolitic-like clasts;

$\mathbf{L t}=\mathbf{L}+\mathbf{Q p}$, where: $\mathbf{L t}=$ total lithic fragments (both unstable and quartzose);

$\mathbf{M s}=$ micas and/or chlorites in single grains; $\mathbf{O p}=$ opaque minerals, $\mathbf{M t}=$ siliciclastic matrix;

$\mathbf{C m}=$ carbonate cement; $\mathbf{L} \mathbf{c}^{*}=$ carbonate rock fragments (also including the chert clasts, $\mathbf{C h}$ ).

1) abundance of lithic fragments (carbonate and ophiolite-like clasts, and, subordinately, epimetamorphic and plutonic rock fragments), quartz grains and low percentages of feldspars (mainly plagioclase single grains). 


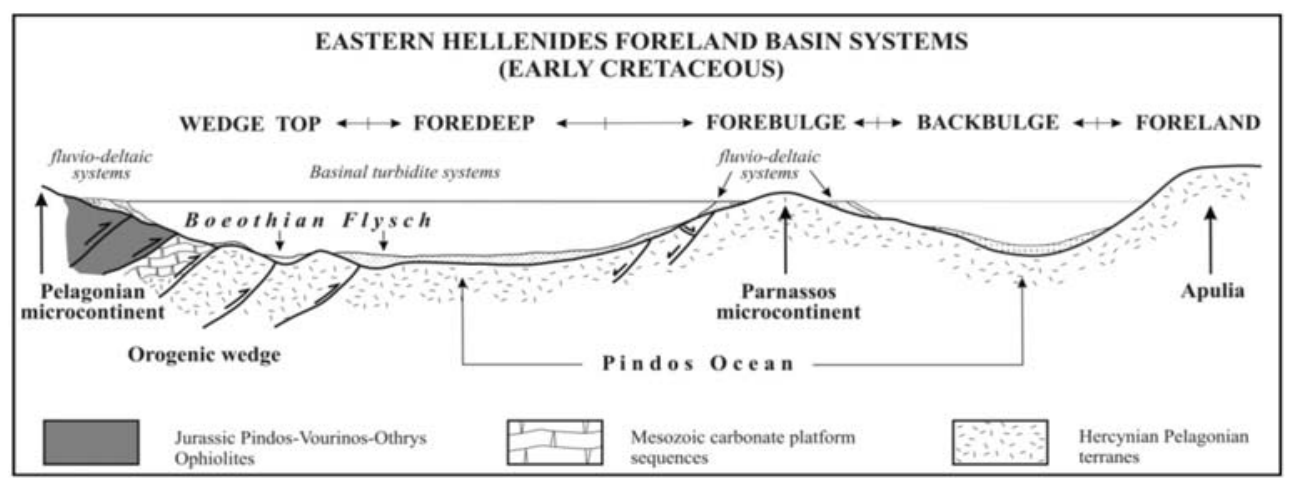

Fig. 5: Early Cretaceous palaeogeography of the Boeothian Flysch basin (i. e. Pindos Ocean) in the context of a foreland basin system showing the uplift processes in the sediment sources (Pelagonian microcontinent), connected with their incipient deformation.

The ophiolitic clasts are usually sub-rounded with a porphyritic-like texture characterized by plagioclase phenocrysts, set in fine-grained groundmass.

Epimetamorphic rock fragments (mainly phillites and metapelites) show very frequent polycrystalline detrital quartz grains with crenulated and sutured crystal-crystal boundaries, whose provenance is connected to low rank metamorphic sources.

Finally, feldspars are very scarce and mainly represented by single grains of plagioclase crystals whose content never exceeds the $7 \%$; K-feldspar is nearly always absent and its presence is only recorded in traces, within some very rare coarse-grained plutonic-like rock fragment.

In conclusion, the composition of the Boeothian Flysch sandstones can be related to the litharenite clan (sensu Folk 1974), well marked by a middle-low textural maturity, due to (i) the sub-angular to sub-rounded shape of the grains, to (ii) a very poor sorting and to (iii) locally abundant siliciclastic matrix. These characters strongly points to very short transports, probably related to a rugged topography, as a consequence of a very unstable tectonic setting, and to a location of the sedimentary basin very near to the source areas.

In Table 2 and Figure 4, the detrital modes of the Boeothian Flysch sandstones are compared to those of Maghrebian Early Cretaceous flysch (Jebel Tisirène, Guerrouch and Monte Soro Flysch), of Late Cretaceous turbidites of northern Apennines (Gottero Sandstones) and of the eastern Carpathians Early Cretaceous Sinaia Flysch.

In particular, the Q-F-L ternary plot clearly displays the different gross compositions between the above-mentioned Early Cretaceous flysch, closely related to different source rocks.

The main difference is the absence of ophiolitic detrital supply in the Early Cretaceous Maghrebian flysch. The Maghrebian Basin, in fact, seems to have been mainly developed on thin continental crust and, locally, it experienced only a partial oceanization, as testified by the occurrence of Middle to Upper Jurassic slices of basic rocks with an E-MORB affinity, scattered in the Rifian Chain (Morocco) and in Sicily (Durand-Delga et al. 2000). Otherwise, the other sectors of the Alpine Tethys reached real oceanic conditions, testified by ophiolitic slices, olistoliths or slideblocks, included within the Cretaceous sedimentary deposits of the Ligurian-Piedmont Basin (Rampone and Piccardo, 2000). 


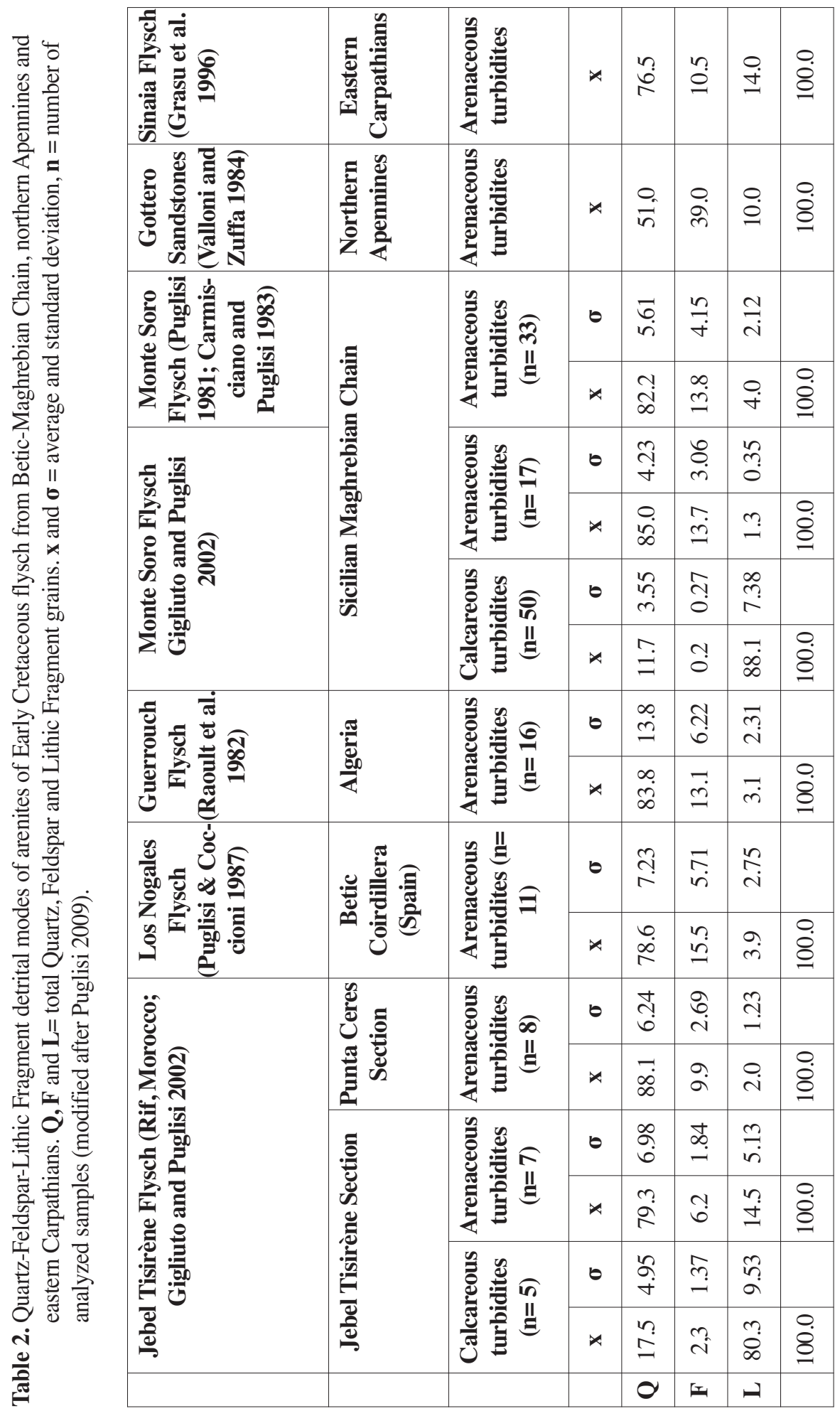


Table 3. Semiquantative mineralogical analysis of sandstones from the Boeothian Flysch

\begin{tabular}{|c|c|c|c|c|c|c|c|c|c|}
\hline Sample & Qtz & Fl & Cc & ill & K & Chl & sm & m/l & Total clays \\
\hline F1 & 21 & 13 & 25 & 12 & 8 & 3 & 17 & 1 & 40 \\
\hline F2 & 50 & 12 & 7 & 9 & 6 & 2 & 13 & 1 & 30 \\
\hline F3 & 46 & 4 & 10 & 6 & 3 & 4 & 25 & 2 & 34 \\
\hline F4 & 38 & 9 & 23 & 7 & 7 & 6 & 7 & 3 & 30 \\
\hline F5 & 39 & 10 & 21 & 10 & 10 & 4 & 4 & 2 & 30 \\
\hline F6 & 37 & 4 & 22 & 14 & 12 & 4 & 5 & 2 & 37 \\
\hline F7 & 40 & 9 & 9 & 13 & 16 & 3 & 6 & 3 & 42 \\
\hline F8 & 35 & 11 & 10 & 13 & 9 & 6 & 12 & 4 & 44 \\
\hline F9 & 30 & 6 & 6 & 14 & 11 & 5 & 24 & 4 & 58 \\
\hline F10 & 17 & 7 & 27 & 27 & 11 & 5 & 0 & 5 & 50 \\
\hline F11 & 27 & 8 & 16 & 18 & 7 & 6 & 14 & 3 & 49 \\
\hline F12 & 26 & 6 & 18 & 8 & 5 & 10 & 23 & 3 & 50 \\
\hline F13 & 30 & 6 & 14 & 7 & 5 & 14 & 20 & 4 & 50 \\
\hline F14 & 42 & 13 & 15 & 8 & 5 & 4 & 11 & 1 & 29 \\
\hline F15 & 15 & 12 & 15 & 21 & 6 & 10 & 18 & 3 & 59 \\
\hline F16 & 57 & 10 & 3 & 3 & 3 & 4 & 14 & 4 & 30 \\
\hline F17 & 57 & 9 & 6 & 7 & 10 & 6 & 4 & 2 & 29 \\
\hline
\end{tabular}

Explanatory notes: $\mathrm{Qtz}=$ quartz, $\mathrm{Fl}=$ feldspar and plagioclase, $\mathrm{Cc}=$ calcite, $\mathrm{Chl}=$ chlorite, $\mathrm{K}=$ kaolinite, $\mathrm{ill}=$ illite, $\mathrm{sm}=$ smectite, $\mathrm{m} / \mathrm{l}=$ mixed layers.

The gross composition of the Boeothian Flysch sandstones has also been checked by means of semiquantitative mineral phase analyses obtained with diffractometric methodologies (Table 3)

Mineralogical analysis was carried out by using an X-Ray powder Diffractometer of Siemens D-5005 type, with copper tube and graphite monochromatographer.

The mineralogical phases were determined by using computer and the software of SOCABIM Company (DIFRAC PLUS 2004, EVA ver. 10) and the files of JCPDS, at the laboratories of the University of Athens, Faculty of Geology and Geoenvironment.

Semiquantative analyses were estimated according to Cook et al (1975) proposed method.

Representative samples were analysed for their mineralogical composition in order to determine the variations of clastic, carbonate and clay fractions. All samples belong to the outcrop located along the old National Road, $500 \mathrm{~m}$ before the intersection to Evaggelistria village.

The XRD analysis revealed that the mineralogical composition is mostly characterized by quartz, feldspars, calcite and clay minerals (Table 3). The clay minerals are illite, kaolinite, chlorite, smectite, and mixed layers. The quartz and calcite contents seem to be competitive, as expected. The total clay fraction represents both clastic and clays formed by alteration, as a consequence of that, there 
is no direct relation between total clay amount and quartz. The relative high total clay minerals portion, ranging between $29 \%$ and $59 \%$, is represented by poorly crystallised minerals, indicative of intense alteration processes of the primary clastic minerals.

\section{Conclusive remarks}

Detrital modes of the Boeothian Flysch sandstones suggest a provenance from internal domains, which can tentatively be identified with the Hercynian Pelagonian terranes and their Mesozoic carbonate covers and with ophiolitic complexes.

Pelagonian zone, in fact, has recently been interpreted as a Hercynian continental fragment of Gondwanan affinity (Robertson and Mountrakis 2006; Himmerkus et al. 2007), covered by a thick and widespread Mesozoic carbonate platform.

Furthermore, ophiolitic nappes were detached onto this platform as a consequence of the obduction processes occurred in the western margin of the adjacent Vardar Ocean since Late Jurassic (Eohellenic orogenic phase, Auct.).

In particular, the ophiolite-like detritus can be derived from the western side of the Vardar Ocean (i. e. Pindos-Vourinos-Othris Ophiolites; Robertson and Mountrakis 2006) and it can not to be correlated to the so-called Vardar-Axios Ophiolites. These last, in fact, seem to have been tectonically emplaced onto the Pelagonian massif during Cretaceous times (Van Hinsbergen et al. 2009, and references therein), slightly later the deposition of the Early Cretaceous Boeothian Flysch.

Furthermore, contribution from Mesozoic carbonate sources is testified by the abundance of carbonate clasts, whose litology (mainly calcarenites and reefal limestones) suggests a provenance from widespread Jurassic platforms lcated within the Pelagonian Zone.

Finally, low-rank metamorphic detritus (mainly phyllite and quartzite clasts) has always been recognized in the sandstones of the Boeothian Flysch. Provenance of these clasts can be derived from the Hercynian Pelagonian massif, not yet affected by an Alpine metamorphic overprint.

Moreover, we consider that the western part of the Pelagonian microcontinent (i. e. the Boeothian and Parnassos domains), uncovered by ophiolite nappes, formed the foreland basin system (sensu DeCelles and Gilles 1996) of the orogeny.

During Early Cretaceous times, in fact, the Boeothian domain corresponded to the foredeep depozone of the foreland basin system, filled by material derived from the erosion of the emerged ophiolites and its Pelagonian basement, whereas the Parnassos domain, west of the Boeothian foredeep, could correspond to the forebulge depozone of the same system, separated from the Apulian continent by a westernmost small oceanic strand of the Pindos Ocean, as a probable backbulge (Fig. 5).

The following westward migration of the orogeny is marked by the Paleogene flysch of the Parnassos area, which started when this zone was transformed into a foredeep depozone.

In conclusion, on the basis of the detrital modes, provenance and tectonic framework of the Boeothian Flysch, we emphasize its belonging to the Early Cretaceous flysch family, cropping out along all the western and central European Alpine Chains, from the Gibraltar Arc to the Balkans.

\section{References}

Biju-Duval B., Decourt J. and Le Pichon X., 1977. From the Tethys ocean to the Mediterranean seas: a plate tectonic model of the evolution of the western Alpine system. In: Structural history of the 
mediterranean basins, Biju-Duval, B., and Montadert, L. (eds.). XXV Congrès de la Commission Internationale pour l'Exploration Scientifique de la Mediterranée, Split, Yugoslavie, 25-29 October, 143-164.

Carmisciano R. and Puglisi D., 1983. Petrographic study of the Monte Soro Flysch sandstones (Nebrodi Mts., central-northern Sicily). Mineralogica Petrogrographica Acta, 27, 73-90 (in Italian with English abstract).

Clément B., 1971. Découvert d'un flysch éocretacé en Béotie (Grèce continental. Comptes Rendus de la Académie des Sciences de Paris, 272, 791-792.

Celet P., Clément B., Legros G., 1974. A boeothian flysch within the Parnasse domain (continental Greece). Comptes Rendus de la Académie des Sciences de Paris, 278, 1689-1692 (in French with English abstract).

Celet P., Clément, B. and Ferrière J., 1976. The Boeothian zone in Greece; palaeogeographic and structural implications. Eclogae Geologicae Helvetiae, 69 (3), 577-599 (in French with English abstract).

Channell J. E. T. and Kozur H. W., 1997. How many oceans? Meliata, Vardar, and Pindos oceans in Mesozoic Alpine paleogeograpgy. Geology, 25, 183-186.

Clément B., 1971. An Early Cretaceous flysch in the Boeothian area (continental Greece). Comptes Rendus de la Académie des Sciences de Paris, 272, $791-792$ (in French with English abstract).

Clift P. D., 1992. The collision tectonics of the southern Greek Neotethys. Geologische Rundschau, 81, 669-679.

Csontos L. and Vörös A., 2004. Mesozoic plate tectonic reconstruction of the Carpathian region. Palaeogeography, Palaeoclimatology, Palaeoecology, 210, 1-56.

Cook H. E., Johnson P. D., Matti J. C. and Zemmels I., 1975. Methods of sample preparation and X-ray diffraction data analysis, X-ray Mineralogy Laboratory, Deep Sea Drilling Project, University of California, Riverside. In Hayes D. E., Frakes L. A. et al., Init. Repts. DSDP, 28: Washington (U.S. Govt. Printing Office), 999- 1007.

Decelles P. G. and Giles K. A., 1996. Foreland basin systems. Basin Research, 8, 105-123.

Degnan P. J. and Robertson A. H. F., 1998. Mesozoic-early Tertiary passive margin evolution of the Pindos ocean (NW Peloponnese, Greece). Sedimentary Geology, 117, 33.

Durand-Delga M., Rossi Ph., Olivier Ph. and Puglisi, D., 2000. Structural setting and ophiolitic nature the Jurassic basic rocks associated to the Maghrebian flysch in the Rif (Morocco) and Sicily (Italy). Comptes Rendus de la Académie des Sciences de Paris, 331, 29-38 (in French with English abstract and an English abridged version).

Folk R. L., 1974. Petrology of sedimentary rocks. Hemphill's, Austin, Texas, 182 p.

Gazzi P., Zuffa G. G., Gandolfi G. and Paganelli L., 1973. Provenance and dispersal of the sands of the Adriatic beaches between the Isonzo and Foglia mouths: regional setting. Memorie della Società Geologica Italiana, 12, 1-37 (in Italian with English abstract).

Gigliuto L. G. and Puglisi D., 2002. Early Cretaceous turbiditic sedimentation along the Betic-Maghrebian Chain: detrital modes of the sandstones, provenance and palaeogeographic implications. Geologica Carpathica, 53, 4-7

Graham S. A., Ingersoll R. V. and Dickinson W. R., 1976. Common provenance for lithic grains in Carboniferous sandstones from the Ouachita Mountains and Black Warrior Basin. Journal of Sedimentary Petrology, 46, 620-632.

Grasu C., Catană C. and Boboş I., 1996. Petrography of the flysch formations of the inner Carpathians. Editura Tecnica, Bucureşti (Romania), 178 pp. (in Romanian with English abstract).

Himmerkus F., Anders B., Reischmann D. and Kostopoulos D., 2007. Gondwana-derived terranes in north- 
ern Hellenides. In: 4-D Framework of Continental Crust, Hatcher, R. D. Jr., Carlson, M. P., McBride, J. H., and Martinez Catalán, J. R. (eds.), Geological Society of America Memoir, 200, 379-390.

Newmann P. and Zacher W., 2004. The Cretaceous sedimentary history of the Pindos Basin (Greece). International Journal of Earth Sciences, 93, 119-131.

Oszczypko N., 2006. Late Jurassic-Miocene evolution of the Outer Carpathian fold-and-thrust belt and its foredeep basin (Western Carpathians, Poland). Geological Quarterly, 50 (1), 169-194.

Plašienka D., 2003. Dynamics of Mesozoic pre-orogenic rifting in the Western Carpathians. Mitteilungen der Österreichischen Geologischen Gesellschaft, 94, 79-98.

Puglisi D., 1981. Geological-petrographic study of the Monte Soro Flysch (western Peloritani Mts., Sicily). Mineralogica et Petrographica Acta, 25, 103-115 (in Italian with English abstract).

Puglisi D., 2009. Early Cretaceous flysch from Betic-Maghrebian and Europe Alpine Chains (Gibraltar Strait to the Balkans); comparison and palaeotectonic implications. Geologica Balcanica, 37, $3-4$, in press.

Puglisi D. and Coccioni R., 1987. The Los Nogales Flysch (Cretaceous, Betic Cordillera): compositional study and comparison with the Monte Soro Flysch of the Sicilian Maghrebian Chain. Memorie della Società Geologica Italiana, 38, 577-591 (in Italian with English abstract).

Rampone E. and Piccardo G. B., 2000. The ophiolite-oceanic lithosphere analogue: new insights from the Northern Apennines (Italy). In: Ophiolites and Oceanic Crust: New Insights from Field Studies and the Oceanic Drilling Program, Dilek, Y., Moores, E., Elton, D., and Nicolas, A., Geological Society of America Special Paper, 349, 21-34.

Raoult J. F., Renard M. and Melieres F., 1982. The mauretanian Guerrouch Flysch: structural setting, sedimentological and geochemical data (Petite Kabylie, Algeria). Bulletin de la Société Géologique de France, XXIV (3), 611-626. (in French with English abstract).

Robertson A. H. F. and Mountrakis D. 2006. Tectonic development of the Eastern Mediterranean region: an introduction. In: Tectonic development of the eastern Mediterranean region, Robertson, A. H. F., and Mountrakis, D. (eds.), Geological Society Spec. Publ., London, 260, 1-9.

Săndulescu M., 1994. Overview on Romanian geology. ALCAPA II, Field Guidebook, 3-15.

Schmid S. M., Bernoulli D., Fügenschuh B., Matenco L., Schefer S., Schuster R., Tischler M. and Ustaszewski K., 2008. The Alpine-Carpathian-Dinaridic orogenic system: correlation and evolution of tectonic units. Swiss Journal of Geosciences, 101 (1), 139-183.

Schmid S. M., Füegenschuh B., Kissling E. and Schuster R. 2004. Tectonic map and overall architecture of the Alpine orogen. Eclogae Geologicae Helvetiae, 97, 93-117

Stampfli G., 2005. Plate tectonics of the Apulia-Adria microcontinents. In: CROP Project - Deep Seismic explorations of the Central Mediterranean and Italy, Section 11 Geodynamic Evolution: Atlases in Geosciences, Finetti I. R. (ed.), Elsevier, 747-766.

Van Hinsbergen D. J. J., Spakman W., Hafkenscheid E., Meulenkamp J. E. and Wortel M. J. R., 2009. Comparison of geologic reconstructions with tomographic images: deep subduction of continental lithosphere below Greece. Geology, in press.

Zagorchev I., 2001. Introduction to the geology of SW Bulgaria. Geologica Balcanica Special Issue «Geodynamic hazards (earthquakes, landslides), Late Alpine tectonics and neotectonics in the Rhodope Region», 31 (1-2), 3-52. 